\title{
Specific involvement of peripheral T lymphocytes against acetylcholine receptors in myasthenia gravis
}

\author{
BM CONTI-TRONCONI, A SCOTTI, A SGHIRLANZONI, ${ }^{*}$ F CLEMENTI \\ From the Department of Pharmacology and CNR Center of Cytopharmacology, University of Milan and Istituto \\ Neurologico "Besta", Milano, Italy
}

SUMMARY A specific sensitisation of blood $\mathrm{T}$ lymphocytes against the nicotinic acetylcholine receptor has been demonstrated in myasthenic patients. After thymectomy the $T$ lymphocytes response was quickly decreased and in most patients it reached normal values. The $T$ response remained at low or normal levels for at least two years. In patients who had undergone thymectomy three or more years before, a $\mathrm{T}$ lymphocyte response against acetylcholine receptors was frequently detected.

In myasthenia gravis both an antibody response ${ }^{12}$ and a sensitisation of peripheral lymphocytes ${ }^{3-6}$ against nicotinic acetylcholine receptors (AChR) have been described. After thymectomy, the cellular antiAChR response is rapidly and markedly decreased, and in some patients it may reach normal level within a few weeks. ' A role of thymic cells in the pathogenesis of myasthenia gravis is suggested both by the beneficial effects of thymectomy on the evolution of the disease ${ }^{8}$ and by the alterations commonly found in the thymus from myasthenic patients. The most frequent changes have been abnormal numbers of germinal centres ${ }^{9}$ and $\mathrm{B}$ cells. $^{10}$ In myasthenic patients an intrathymic production of anti-AChR antibodies recently has been suggested. "In addition, thymic cells from myasthenic patients selectively enhance the production of anti-AChR antibodies of peripheral lymphocytes. ${ }^{12}$ It has been proposed that this effect could be due to the presence of specific $T$ cells in the thymus. In the experimental animal AChR has been shown to be a T-dependent antigen. ${ }^{13}$ It seems likely that $\mathrm{T}$ lymphocytes also play a role in the development of the autoimmune response against $\mathrm{AChR}$ in myasthenic patients. In the present study a sensitisation against AChR of peripheral lymphocytes from myasthenic patients was demonstrated. This T-response was quickly decreased by thymectomy.

Address for reprint requests: Dr F Clementi, Department of Pharmacology. University of Milan, via Vanvitelli, 32-20129 Milano, Italy.

Received 21 June 1982 and in final revised form 10 February 1983 Accepted 1 April 1983

\section{Patients and methods}

Patients studied Forty-three myasthenic patients, aged from 11 to 62 years were studied ( 34 females and nine males). The duration of the disease was between 2 months and 12 years. The severity of the myasthenic symptoms was classified on the basis of Ossermann and Genkins staging. ${ }^{14}$ Most patients were receiving anticholinesterase drugs and 24 of them were taking prednisone $(10-100 \mathrm{mg}$ on alternate days). In 13 patients the $T$ lymphocyte response was studied both before and after thymectomy. In table 1 the clinical characteristics and treatment of these 13 patients are summarised. Blood lymphocytes from eight healthy subjects in the same age range of the patients were used as controls.

Antigen preparation Purified postsynaptic membrane fragments prepared from the electric organ of Torpedo marmorata $^{15}$ were used as previously described. ${ }^{4}$ The membrane preparations contained at least $0.5 \mathrm{nmols}$ of $\alpha$-bungarotoxin binding sites/mg of protein.

Isolation of T lymphocytes Peripheral lymphocytes (PBL) were isolated from $15-20 \mathrm{ml}$ of blood according to Böyum. ${ }^{16}$ T lymphocytes were isolated from PBL according to the E-rosetting technique of Dean et al $^{17}$ with minor modifications. $E$ rosettes were prepared by mixing equal volumes of PBL $\left(4 \times 10^{6}\right.$ cells $/ \mathrm{ml}$ in RPMI 1640-Hepes buffer, Eurobio, Paris) and sheep erythrocytes (Sclavo, Siena, Italy) $4 \times 10^{8}$ cells $/ \mathrm{ml}$ in the same buffer. The mixture was incubated at $37^{\circ} \mathrm{C}$ for 10 minutes, centrifuged at $40 \mathrm{~g}$ for 5 minutes and incubated for 1 hour at $4^{\circ} \mathrm{C}$. The pellet was gently resuspended and centrifuged on a cold Ficoll gradient for 1 hour at $200 \mathrm{~g}$ and $4^{\circ} \mathrm{C}$. The rosette forming cells (RFC) were recovered as a pellet and the adhering erythrocytes were lysed with a $10 \mathrm{~min}$ incubation at $37^{\circ} \mathrm{C}$ in Boyle's solution. RFC were washed three times with Hanks solution and resuspended in RPMI-Hepes buffer supplemented with $10 \%$ autologous serum $\left(1 \times 10^{6}\right.$ cells $\left./ \mathrm{ml}\right)$. The RFC popula- 
Table 1 Clinical characteristics of the myasthenic patients whose lymphocyte reactivity was followed after thymectomy

\begin{tabular}{|c|c|c|c|c|c|c|c|c|c|}
\hline \multirow[t]{2}{*}{$\begin{array}{l}\text { Patients } \\
\text { No }\end{array}$} & \multirow[t]{2}{*}{ Sex } & \multirow{2}{*}{$\begin{array}{l}\text { Age of onset } \\
\text { of myasthenia } \\
\text { gravis (yr) }\end{array}$} & \multirow{2}{*}{$\begin{array}{l}\text { Age at } \\
\text { thymectomy } \\
\text { (yr) }\end{array}$} & \multirow[t]{2}{*}{$\begin{array}{l}\text { Thymic } \\
\text { histology }\end{array}$} & \multirow{2}{*}{$\begin{array}{l}\text { Clinical state } \\
\text { before } \\
\text { thymectomy }\end{array}$} & \multicolumn{3}{|c|}{$\begin{array}{l}\text { Clinical state after } \\
\text { thymectomy }\end{array}$} & \multirow[t]{2}{*}{ Therapy* } \\
\hline & & & & & & $6 m$ & $l y r$ & $2 y r$ & \\
\hline 1 & $\mathrm{~F}$ & 21 & 21 & hypertrophy & $2 A$ & $2 A$ & $2 \mathrm{~A}$ & $\mathbf{R}$ & none \\
\hline 2 & $\mathrm{~F}$ & 20 & 21 & inge, ", & 3 & $2 \mathrm{~B}$ & $2 \mathrm{~A}$ & $2 \mathrm{~A}$ & prednisone $85 \mathrm{mg}$ ad (12) \\
\hline 3 & $\mathrm{~F}$ & 9 & 17 & $" \prime$ & $2 \mathrm{~A}$ & RF & RF & RF & none \\
\hline 4 & $\mathrm{~F}$ & 17 & 19 & "' & $2 B-2 A$ & RF & RF & RF & prednisone $25 \mathrm{mg}$ ad (4) \\
\hline 5 & $\mathbf{M}$ & 36 & 33 & $\prime \prime$ & $2 A$ & - & - & $2 \mathrm{~B}$ & prednisone $85 \mathrm{mg}$ ad (5) \\
\hline 6 & $\mathbf{F}$ & 15 & 18 & $\prime \prime$ & 2A-B & 1 & RF & RF & prednisone $25 \mathrm{mg}$ ad (36) \\
\hline 7 & $\mathrm{~F}$ & 10 & 11 & $\because \prime$ & $2 \mathrm{~A}$ & RF & RF & RF & none \\
\hline 8 & $\mathrm{~F}$ & 18 & 20 & "' & $2 A$ & $2 A$ & $2 \mathrm{~A}$ & $2 A$ & none \\
\hline 9 & $\mathbf{F}$ & 34 & 38 & $\prime \prime$ & $2 \mathrm{~A}$ & - & RF & - & prednisone $75 \mathrm{mg}$ ad (24) \\
\hline 10 & $\mathrm{~F}$ & 26 & 31 & $" \prime$ & - & 2B & $2 \mathrm{~B}$ & - & prednisone $125 \mathrm{mg}$ ad (36) \\
\hline 11 & $\mathbf{F}$ & 57 & 59 & $" \prime$ & $2 \mathrm{~A}$ & - & - & - & none \\
\hline 12 & $\mathrm{~F}$ & 46 & 46 & ", & $2 A$ & RF & - & - & none \\
\hline 13 & $\mathbf{M}$ & 30 & 40 & thymoma & $2 \mathrm{~A}$ & RF & - & RF & prednisone $10 \mathrm{mg}$ ad (36) \\
\hline
\end{tabular}

${ }^{*} \mathrm{ad}=$ alternate days; numbers in brackets indicate the months of steroid treatment.

tion (T-cells) consisted of $98 \%$ lymphocytes without surface immunoglobulins.

Lymphocyte stimulation RFCs were cultured according to the micromethod of Hartzman et al ${ }^{18}$ and challenged, as previously described, ${ }^{4}$ with a postsynaptic membrane fraction of Torpedo electric organ, rich in $\mathrm{AChR}$, at a final concentration of $0 \cdot 1,0 \cdot 25,0 \cdot 5,0 \cdot 75 \mathrm{mg} / \mathrm{ml}$. Lymphocytes were cultured for 4 days at $37^{\circ} \mathrm{C}$ in a moist atmosphere of 95\% air and 5\% $\mathrm{CO}_{2}$. About 20 hours before ending the culture, $0 \cdot 8 \mu \mathrm{Ci}$ of ${ }^{3} \mathrm{H}$-thymidine (Sorin, Saluggia, Italy) was added. Cells were harvested by a Skatron Multicell harvester on filter paper disks, and radioactivity was counted in a liquid scintillation spectrometer using a toluene-scintiilation mixture.

Lymphocytic stimulation was expressed as a Stimulation Index, that is the ratio between the ${ }^{3} \mathrm{H}$-thymidine incorporation in the presence of AChR and the basal incorporation. In the control group, the Stimulation Indices obtained ranged between 0.6 and $1 \cdot 3$. Stimulation Indices higher than 1.5 were considered abnormal, since they were more than two standard deviations above the mean Stimulation Index of the control group.

\section{Results}

The Stimulation Indexes induced by AChR in culture of lymphocytes able to form E-rosettes demonstrate the existence of a sensitisation of T-lymphocytes from myasthenic patients against this antigen (fig 1). The mean Stimulation Index for myasthenic patients was $2 \cdot 30 \pm 0 \cdot 27$ which was higher than that of the control group $(0 \cdot 86 \pm 0 \cdot 1, p<0 \cdot 01)$. The distribution of the Stimulation Indices of RFC from myasthenic patients is very broad. Only about $50 \%$ of them are above 1.5 which we considered the upper limit for a normal response.

In a previous work ${ }^{7}$ we found that thymectomy caused a rapid decrease of the response to AChR of PBL from myasthenic subjects. For this reason we tested the effect of thymectomy in the response to AChR of RFC. The results are shown in fig 2. All the patients who had a positive RFC response before

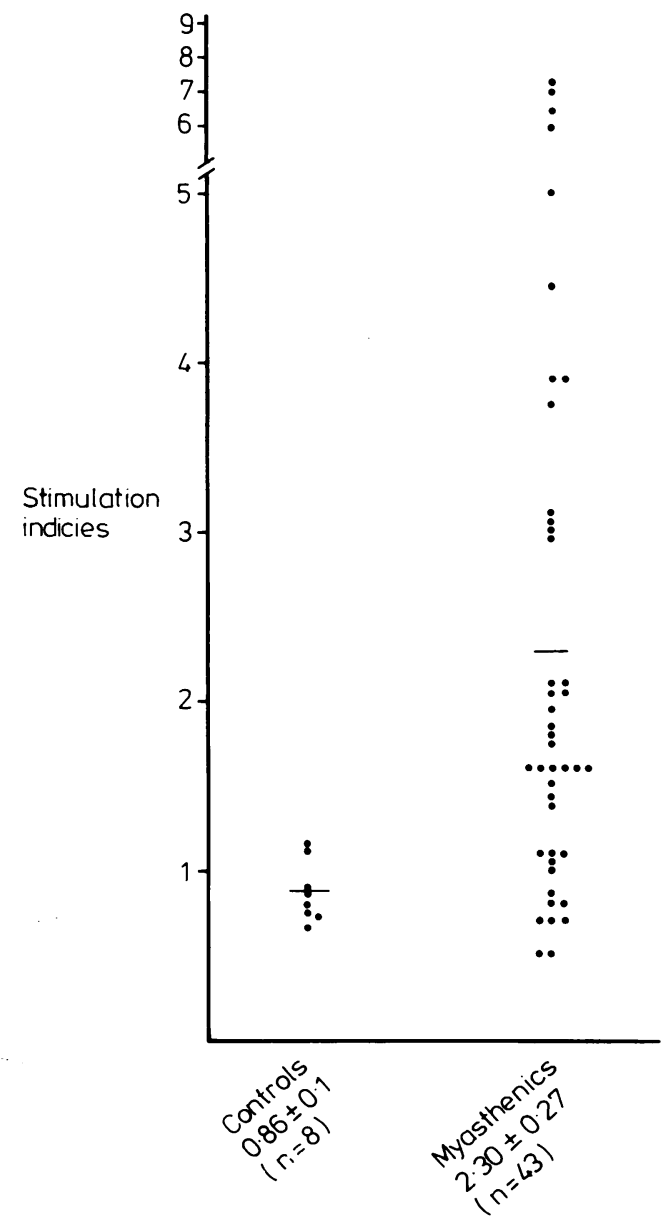

Fig 1 Individual SIs obtained testing rosette-forming cells (RFC) from myasthenic patients and controls with AChR. The numbers indicate the mean $S I \pm$ standard error of the mean. The numbers in brackets indicate the number of determinations. 


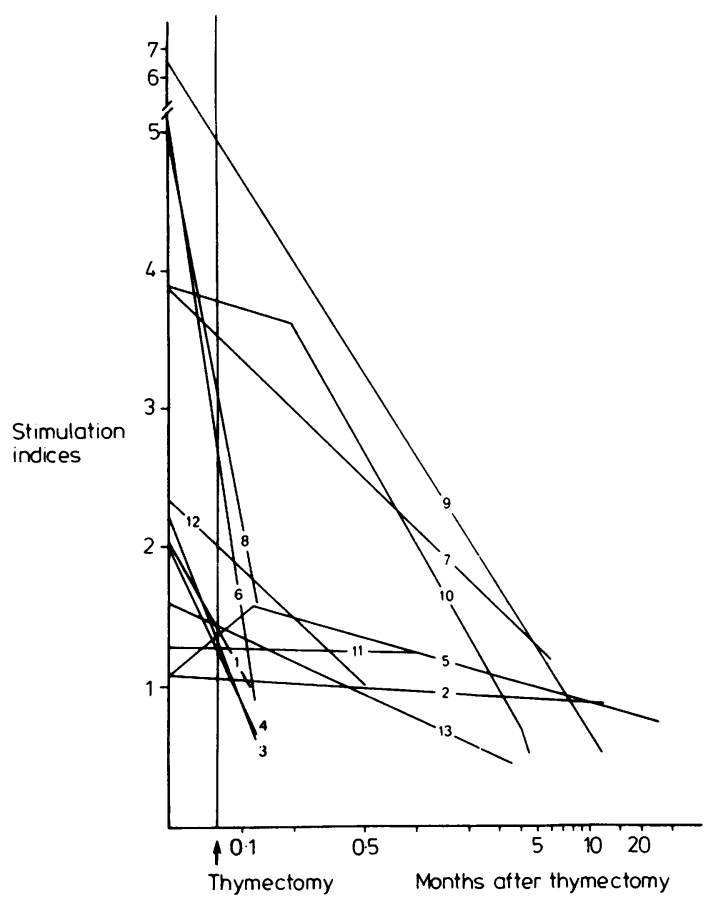

Fig 2 Stimulation Indexes obtained from RFC of 13 patients tested before and at various time intervals after thymectomy. The numbers on the lines identify the patients whose clinical history is reported in table 1.

thymectomy showed a remarkable reduction of this response to AChR after thymectomy. We did not observe any difference between patients who were submitted to thymectomy or to thymectomy and steroid treatment.

In order to assess if this effect of thymectomy was long lasting, we tested the sensitisation of RFC to $\mathrm{AChR}$ in myasthenic patients grouped according to the time elapsed from the thymectomy and in patients who had not been submitted to thymectomy. In the patients who had the thymus removed no longer

Table 2 Mean Stimulation Index of RFC of myasthenic patients before and after thymectomy

\begin{tabular}{|c|c|c|c|}
\hline Patients & $\begin{array}{l}\text { Number } \\
\text { of cases }\end{array}$ & $\begin{array}{l}\text { No of } \\
\text { determinations }\end{array}$ & $S I \pm S E$ \\
\hline \multirow{4}{*}{$\begin{array}{l}\text { No thymectomy } \\
0-2 \text { years after } \\
\text { thymectomy } \\
\text { 3-4 years after } \\
\text { thymectomy } \\
5-6 \text { years after } \\
\text { thymectomy }\end{array}$} & 26 & 28 & $2 \cdot 47 \pm 0 \cdot 36^{*}$ \\
\hline & 25 & 35 & $1 \cdot 18 \pm 0 \cdot 11^{\dagger}$ \\
\hline & 5 & 11 & $2 \cdot 47 \pm 0 \cdot 62 \ddagger$ \\
\hline & 4 & 5 & $3.6 \pm 0.98 \ddagger$ \\
\hline
\end{tabular}

than two years before, the Stimulation Indices of RFC were lower $(1 \cdot 18 \pm 0 \cdot 11$ versus $2 \cdot 47 \pm 0 \cdot 36, p<$ 0.01 , see table 2). However, in the patients who had been submitted to thymectomy three years or more, the Stimulation Indices of RFC were not different from the pre-thymectomy group (table 2).

The reactivity against AChR of RFC also was compared between the patients who were receiving corticosteroid therapy and those who were not taking this medication. No difference was detected $(2 \cdot 26 \pm$ $0 \cdot 28, \mathrm{n}=26$ versus $1 \cdot 85 \pm 0 \cdot 25, \mathrm{n}=28$ ).

\section{Discussion}

The results presented here demonstrated that in human myasthenia gravis the autoimmune response against AChR involved the participation of specifically sensitised $T$ lymphocytes. The mean Stimulation Index obtained for RFC of myasthenic patients was relatively low. This could be due to two reasons: (1) the low immune cross-reactivity between Torpedo and mammalian muscle $\mathrm{AChR}^{19}$ despite the extensive homology in the primary structure of the AChR molecule from these two sources, ${ }^{20}$ and (2) the existence among myasthenic patients of different groups regarding the in vitro responsiveness to $\mathrm{AChR}$ of peripheral lymphocytes. In fact, older patients ${ }^{4}$ and patients submitted to thymectomy' did not respond in vitro to the presence of AChR.

The key role of the thymus in the expression of the autoimmune response to AChR has been a hypothesis since the effectiveness of thymectomy on the myasthenic symptoms was demonstrated. Experimental evidence of a direct effect of thymus cells on the modulation of the peripheral anti-AChR antibody response had been recently reported. ${ }^{12}$ The drastic and prompt effect of thymectomy on the response of peripheral T-cells to AChR is further evidence of a direct functional link between the peripheral lymphoid cells and the thymus in the expression of the anti-AChR response. The effect of thymectomy seems specific for $\mathrm{AChR}$ antigen since it has been previously reported that the response to other antigens such as mumps, Candida albicans, purified protein derivative, and mitogens, such as PHA, Con A, PWM, is not affected by thymectomy. ${ }^{21}$ The efficacy of thymectomy could be due either to the removal of a reservoir of specifically sensitised $T$ cells, or to the removal of cells producing a specific circulatory factor. It should be noticed that at least in the group of patients we studied (table 1) the decrease in the RFC response to AChR after thymectomy (fig 2) was in general accompanied by a clinical improvement of myasthenic symptoms, except for patients 8 and 10 who had a decreased 
Stimulation Index but did not improve after thymectomy.

This effect of thymectomy on the anti AChR response of RFC does not last indefinitely, since 3 years after surgery the RFC response was again the same as in the pre-thymectomy patients, and even higher after 5 or more years. These modifications in time are difficult to interpret since the long term effect of thymectomy on immunological response is poorly understood. This late return to abnormal Stimulation Indices could be due (a) to the presence of residual fragments of thymus after the surgery or of ectopic thymuses, ${ }^{8}$ (b) to the development of thymuslike functions by peripheral lymphoid tissues, (c) to a slow disappearance of some lymphocyte functions, as suggested by Wijermans $e t a^{21}$ who found that 5 years after thymectomy myasthenia gravis patients had a decreased response to mitogens and decreased cytotoxic $T$ cell response in cell-mediated lympholysis. Half of our patients had, after thymectomy, a corticosteroid therapy and this could have contributed to the decrease of the Stimulation Index we have observed. However, the effect of corticosteroid therapy on the cellular response to AChR is always mild, as Abramsky et al $^{22}$ and ourselves ${ }^{7}$ have reported, and in this series of experiments the difference between corticosteroid-treated and non-treated patients was not statistically significant. Furthermore three cases which improved after thymectomy without steroid treatment had a decrease in Stimulation Index.

In conclusion, thymectomy had a large effect on the peripheral lymphocytes of myasthenic subjects, and in particular on their T-cells, which is the only specific effect of this treatment detected so far on the immune response to AChR in these patients. The decrease of rosette forming cells response appears to correlate with the clinical improvement of most of these patients. In this respect the long term return of the RFC response against $A C h R$ may explain some of the late failures of thymectomy in controlling the evolution of Myasthenia.

We thank Dr Cecilia Gotti for the generous gift of Torpedo membranes used in these experiments.

\section{References}

1 Drachman DB. Myasthenia Gravis. N Engl J Med 1978; 298:136-42; 189-93.

${ }^{2}$ Lindstrom J, Seybold ME, Lennon VA. Antibody to AChR in myasthenia gravis: prevalence, clinical correlates and diagnostic value. Neurology (Minneap) 1976;26:1054-9.

3 Abramsky O, Aharanov A, Webb C, et al. Cellular immune response to acetylcholine receptor rich fractions in patients with myasthenia gravis. Clin Exp
Immunol 1975;19:11-16.

4 Conti-Tronconi BM, Morgutti M, Sghirlanzoni A, Clementi F. Cellular immune response against AChR in myasthenia gravis: I. Relevance to clinical course and pathogenesis. Neurology (Minneap) 1979;29: 496-501.

5 Richman DP, Antel JP, Patrick JW, Barry JW, Arnason GW. Cellular immunity to acetylcholine receptor in myasthenia gravis: relationship to histocompatibility type and antigenic site. Neurology (Minneap) 1979; 29:291-6.

- Clementi F, Conti-Tronconi BM. Cellular immunity in myasthenia gravis. In: Eldefrawi AT, Albuquerque EX, eds. London: Chapman and Hall, 1983.

7 Morgutti M, Conti-Tronconi BM, Sghirlanzoni A, Clementi F. Cellular immune response to acetylcholine receptor in myasthenia gravis: II. Thymectomy and corticosteroids. Neurology (Minneap) 1979;29: 734-8.

8 McQuillen MP, Leone MG. A treatment carol: thymectomy revisited. Neurology (Minneap) 1977; 27: 103-6.

9 Castleman B. The pathology of thymus gland in myasthenia gravis. Ann NY Acad Sci 1966;135:496-505.

10 Abdou NI, Lisak RP, Zweiman B, Abrahamsohn I, Penn AS. The thymus in myasthenia gravis. Evidence for altered cell populations. N Engl J Med 1974; 291:1271-5.

"Vincent A, Scadding GK, Thomas HC, Newsom-Davis $\mathrm{J}$. In vitro synthesis of anti-acetylcholine-receptor antibody by thymic lymphocytes in myasthenia gravis. Lancet 1978;1:305-7.

12 Newsom-Davis J, Willcox N, Calder L. Thymus cell in myasthenia gravis selectively enhance production of acetylcholine receptor antibody by autologous blood lymphocytes. N Engl J Med 1981;305:1313-8.

13 Lennon VA, Lindstrom JM, Seybold ME. Experimental autoimmune myasthenia gravis: cellular and humoral immune response. Ann NY Acad Sci. 1976;274: 283-92.

14 Ossermann KE, Genkins G. Clinical reappraisal of the use of edrophonium dichloride (Tensilon) test in myasthenia gravis and significance of clinical classification. Ann NY Acad Sci 1966;135:312-9.

is Cohen JB, Weber H, Huchet M, Changeaux JR. Purification from torpedo marmorata electric tissue of membrane fragments particularly rich in cholinergic receptor protein. FEBS Lett 1972;26:43-7.

16 Böyum A. Separation of leucocytes from blood and bone marrow. Scand J Clin Lab Invest (Suppl. 97), 1968; 21:7.

17 Dean JM, Silva JS, McCay JL, Leonard CM, Cannon GB, Herbermann RB. Functional activities of rosette separated human peripheral blood leucocytes. $J$ Immunol 1975;115:1449-55.

18 Hartzman RJ, Segall M, Bach ML, et al. Histocompatibility matching: IV. Miniturization of the mixed leucocyte culture test: a preliminary report. Transplantation 1971;11:268-73.

9 Lindstrom JM, Malcom Campbell BA, Nave BA. Specificities of antibodies to acetylcholine receptors. Muscle Nerve 1978;1:140-5. 
${ }^{20}$ Conti-Tronconi BM, Gotti C, Hunkapiller MN, Raftery MA. The mammalian Acetilcholine receptor: a pentameric structure of homologous subunits. Science 1982, 218: 1127-9.

21 Wijermans P, Oosterhuis HJ, Astaldi GL, Schellekens PTh, Astaldi A. Influence of Adult Thymectomy on immunocompetence in patients with Myasthenia
Gravis. J Immunol 1980;124:1977-82.

22 Abramsky O, Aharanov A, Teitelbaum D, Fuchs S. Myasthenia Gravis and Acetylcholine receptor. Effect of Steroids in clinical course and Cellular Immune Response to Acetylcholine Receptor. Arch Neurol 1975;32:684-7. 